\title{
Patch dynamics of eelgrass Zostera marina
}

\author{
Birgit Olesen, Kaj Sand-Jensen* \\ Department of Plant Ecology, University of Aarhus, Nordlandsvej 68, DK-8240 Risskov, Denmark
}

\begin{abstract}
Eelgrass has declined extensively during the last decades following eutrophication of coastal regions of western Europe and the USA. Recent efforts have been taken to reduce nutrient loading, with the hope of restoring the former widespread populations. We studied fine-scale patch dynamics of eelgrass Zostera marina $L$. in permanent plots outside the continuous vegetation in a protected embayment in Limfjorden, Denmark, to evaluate means of recruitment and rates of expansion and mortality of patches. The size distribution was dominated by small patches which were formed by seedlings at high rates during spring $\left(0.16\right.$ to $\left.0.76 \mathrm{~m}^{-2}\right)$. Mortality was high and only low proportions ( 0 to $24 \%$ ) of the studied cohorts remained as individual patches 1.5 and 2.5 yr later. Patch mortality was restricted to small patches containing $<32$ shoots with a mean age of $<5$ yr. The sharply declining mortality with increasing patch age and size is presumably due to improved anchoring, mutual physical protection and physiological integration among the shoots. The lateral expansion of established patches by centrifugally growing horizontal rhizomes averaged $16 \mathrm{~cm} \mathrm{yr}^{-1}$ and was independent of patch size. With this lateral growth the possible annual areal expansion will be faster in systems with many small patches $\left(260 \%\right.$ in $0.1 \mathrm{~m}^{2}$ patches) and slower in systems with few large patches $(19 \%$ in $10 \mathrm{~m}^{2}$ patches). Successful recovery of the eelgrass vegetation in large systems is, therefore, dependent on seed production and dispersal and subsequent seedling establishment and patch growth.
\end{abstract}

KEY WORDS: Zostera marina Population $\cdot$ Colonization $\cdot$ Patch dynamics

\section{INTRODUCTION}

The areal cover of seagrasses undergoes extensive natural fluctuations due to variable growth conditions and catastrophic declines during storm events (Birch \& Birch 1984, den Hartog 1987, Williams 1988, Larkum \& den Hartog 1989) and epidemic diseases (Giesen et al. 1990). More recently, cultural eutrophication and intensified coastal development have severely reduced seagrass abundance and alarmed marine ecologists and responsible politicians (Kemp et al. 1983, Cambridge \& McComb 1984, Giesen et al. 1990, Larkum \& West 1990). Although seagrass decline occurs worldwide, studies of the dynamics of seagrass cover and the associated colonization, expansion-recession, and mortality processes are few (Birch \& Birch 1984, Brouns 1987, Williams 1988, Duarte \& Sand-Jensen 1990a, b, Williams 1990).

\footnotetext{
- Present address: Freshwater Biological Laboratory, University of Copenhagen, Helsingørsgade 51, DK-3400 Hillerød, Denmark
}

Eelgrass Zostera marina (L.) has undergone similar changes in areal cover throughout most of its distribution range in Europe and the USA, including a widespread recent decline (den Hartog \& Polderman 1975, Rasmussen 1977, Orth \& Moore 1983a, Phillips 1984, den Hartog 1987, Giesen et al, 1990). Encouraging examples of eelgrass recovery remain few (Wyer et al. 1977, Verhagen \& Nienhuis 1983, Harrison 1987). For example, eelgrass covered about $7000 \mathrm{~km}^{2}$ of the inner coastal Danish waters early in this century (Petersen 1914). The 'eelgrass wasting disease' in the early 1930 s destroyed most eelgrass meadows, and in 1942 the areal cover of eelgrass was only $540 \mathrm{~km}^{2}$ (Rasmussen 1977). After a phase of re-establishment, eutrophication has subsequently led to further reduction of eelgrass cover since the 1970 s (Orth \& Moore 1983a, den Hartog 1987). The eelgrass populations present today are mainly small and confined to shallow protected areas and should have great difficulties in expanding to the larger, more exposed and deeper regions because of insufficient seed input, greater physical disturbance and poorer light conditions than during the 
former periods of widespread eelgrass coverage. However, a planned reduction in nutrient loading to Danish waters by $80 \%$ for $\mathrm{P}$ and $50 \%$ for $\mathrm{N}$ before 1995 aims at reducing phytoplankton development and restoring the former eelgrass populations. The likelihood and possible time scales of eelgrass recovery remain as yet unknown.

Eelgrass meadows are maintained principally by vegetative production of lateral shoots (Olesen \& SandJensen 1994) and areal expansion is probably limited by the slow growth rate of horizontal rhizomes (SandJensen 1975). Colonization of new areas should depend on the dispersal and subsequent germination of seeds and, therefore, on the distance to reproductive stands and the maintenance of adequate conditions for seedling establishment and growth. Patch mortality is likely to decline with increasing patch size (e.g. Duarte \& Sand-Jensen 1990a, Sand-Jensen \& Madsen 1992) because of mutual protection among neighbour plants. Lateral spread and shoot growth may also depend on patch size, such that shoot mortality may be high and areal expansion slow until a certain critical minimum patch size is reached (Duarte \& Sand-Jensen 1990a, b).

We provide here a first step to evaluate eelgrass patch dynamics by determining (1) the formation and size-dependent mortality of eelgrass patches, (2) the lateral spread of differently sized patches and (3) shoot growth rate as a function of patch size and position within the patch. We restricted the investigation to a single site in a protected Danish embayment during a $2.5 \mathrm{yr}$ period and concentrated on the short-term dynamics of predominantly small patches characterized by high turnover. We acknowledge that more sites of different exposure and longer time periods, particularly for large patches, are needed to establish a more comprehensive knowledge of eelgrass population dynamics.

\section{METHODS}

Study area. Eelgrass patch dynamics were investigated from May 1990 to September 1992 in a small (1.6 km²) semi-enclosed embayment of Limfjorden, a shallow eutrophic brackish-water area $\left(1500 \mathrm{~km}^{2}\right)$ in northern Jutland, Denmark. The embayment studied is $1.7 \mathrm{~km}$ long and $1.4 \mathrm{~km}$ wide at the entrance. The effective fetch, estimated according to Smith (1979), was short $(0.51 \mathrm{~km})$ towards the prevailing westerly winds, indicating relatively high protection. The embayment is $2 \mathrm{~m}$ deep at the entrance, and slopes to a depth of about $1 \mathrm{~m}$ in the central part. Mean tidal range is $0.15 \mathrm{~m}$, but wider fluctuations in water level are caused by wind. Salinity averages $26 \%$ and water temperature ranged from just below zero to $25^{\circ} \mathrm{C}$ during the study period. A continuous eelgrass meadow covers the central deeper part of the embayment, occupying $52 \%$ of the total area, and is bordered at its upper limit by a fringe (50 to $100 \mathrm{~m}$ wide) of isolated eelgrass patches at mean depths between 0.4 and $0.7 \mathrm{~m}$. This investigation was performed within this shallow zone of eelgrass vegetation.

Eelgrass patch dynamics. Size distribution of eelgrass patches (minimum registered area $0.3 \mathrm{~m}^{2}$ ) within the studied embayment was measured in a $1000 \mathrm{~m}^{2}$ area to include large size-classes.

Small eelgrass patches down to single shoots and their dynamics were studied by mapping the vegetation at intervals of 3 to 12 mo in 2 permanent plots $\left(120 \mathrm{~m}^{2}\right.$ ) established in May 1990 (Plot I) and May 1991 (Plot II). Within each plot a grid was established by placing permanent sticks at $2 \mathrm{~m}$ intervals, onto which an aluminium frame $\left(1 \mathrm{~m}^{2}\right)$ divided into $0.2 \times 0.2 \mathrm{~m}$ squares could be fitted during observations. On each sampling date the position and dimensions of all patches were determined and each patch was identified according to the previous recordings. The origin of new patches appearing between sampling dates, whether developed from seedlings or fragments of former larger patches, was recorded. Newly established seedlings were identified from their morphology (short, narrow-leaved shoots with 1 to 3 leaves). This identification was confirmed outside the permanent plot on harvested seedlings showing remains of the seedling coat and a scorpioid rhizome base (Setchel 1929). The number of shoots in each patch was counted, or in larger patches $\left(>0.1 \mathrm{~m}^{2}\right)$ estimated from the area multiplied by the measured annual mean shoot density of 840 shoots $\mathrm{m}^{-2}$ (Olesen \& Sand-Jensen 1994). Our patch dynamic analysis was based on the distribution in logarithmic size classes that became increasingly wider at higher numbers to make the procedure described above sufficiently accurate. Patch mortality was calculated as the relative number of patches lost within each size-class.

Patch growth. Lateral expansion of patches was determined by measuring the elongation of eelgrass rhizomes from the patch margin into bare sediments for 38 patches ranging widely in size (diameter from 0.2 to $8.1 \mathrm{~m}$ ). Permanent marks were placed at the edge of each patch at 4 positions (N, S, E and $W$ of patch centre) in April 1990 and lateral growth relative to the marks was measured in July and October 1990 and May and September 1991.

Eelgrass shoot growth. The influence of patch size and distance to the patch edge on shoot growth was studied in August by measuring leaf elongation rate normalized to leaf length of shoots at the centre of 5 patches of different size (diameters between 1.2 and $20 \mathrm{~m}$ ) and along transects from the edge $(20 \mathrm{~cm}$ inside 
the patch) to the centre of these 5 patches. We expressed shoot growth as relative leaf elongation rate, analogous to the relative growth rate widely used as the standard for terrestrial plants, also to compensate for the influence of different shoot sizes on growth. Leaf elongation was measured on 10 to 15 shoots in 3 plots at each position by marking the leaves with a needle just above the leaf sheath (Sand-Jensen 1975, Kirkman \& Reid 1979). All marked shoots were retrieved 2 wk later and growth was measured as leaf increment relative to the reference hole on the oldest nongrowing leaf.

\section{RESULTS}

\section{Patch formation and mortality}

Outside the continuous eelgrass meadow most patches were small. The largest patch registered within the $1000 \mathrm{~m}^{2}$ quadrat was $147 \mathrm{~m}^{2}$ and $50 \%$ of all patches were between $0.3 \mathrm{~m}^{2}$ (minimum patch size included) and $2 \mathrm{~m}^{2}$ (Fig. 1)

The size distribution of eelgrass patches within the 2 small $\left(120 \mathrm{~m}^{2}\right)$ permanent plots ranged from a single shoot $\left(0.001 \mathrm{~m}^{2}\right)$ to $23 \mathrm{~m}^{2}$ and was also highly skewed, as $50 \%$ of all patches contained less than 4 shoots in spring and less than 16 shoots in autumn (Figs. $2 \& 3$ ). Small patches were highly dynamic compared to larger ones, with large numbers of small patches being formed during winter and early spring and numbers gradually declining during the growth season. Thus, 89 new patches ( $63 \%$ of total patch number) appeared in Plot I from October 1991 to May 1992

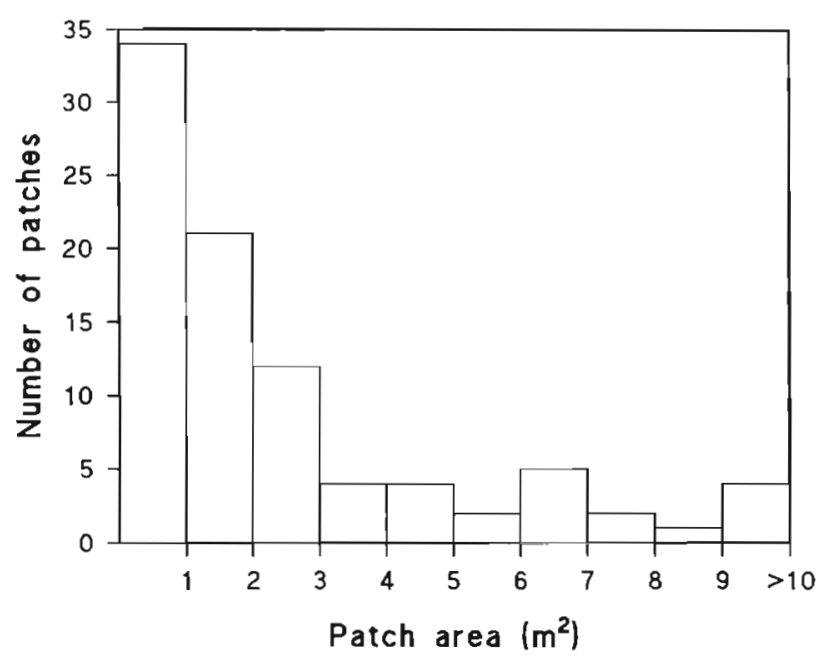

Fig. 1. Zostera marina. Size distribution of eelgrass patches as determined from mapping of the vegetation within an area of $1000 \mathrm{~m}^{2}$ (minimum patch size $0.3 \mathrm{~m}^{2}$ ) and most $(85 \%)$ of them contained 1 or 2 shoots. New patches were formed from seedlings which were the main contributors to the high number of small patches in May 1990 and May 1991 as well as to the overall increase in patch number (Figs. 2, 3 \& 4). No new patches were observed between May and October in 1990 and May and September in 1991 (Fig. 4). Patch formation through entrapment of floating shoots and subsequent rhizome growth was not observed. Additionally, the subdivision of established vegetation along patch edges and reduction of shoot density due to harsh weather conditions during winter added to the number of small patches (Fig. 4B, D). Accordingly, seedling establishment, associated with the transfer of patches to smaller size-classes during winter, led to a 20 -fold increase in the number of patches with 1 or 2 shoots.

Patches were lost throughout the year but at the fastest rates during summer due to high mortality of small, recently established patches (Figs. 2, $3 \& 4 \mathrm{C}$ ) Patch mortality was strongly size-dependent as only patches with less than 32 shoots were lost during the 2 yr study period (Figs. $2 \& 3$ ). The critical minimum size for patch survivorship varied seasonally and tended to be highest during winter (Fig. 2).

The density of new seedlings on bare sediments during spring ranged from 19 seedlings $120 \mathrm{~m}^{-2}$ in 1990 (Plot I) to an average of 78 seedlings $120 \mathrm{~m}^{-2}$ in 1991 (Plots I \& II) (Table 1). Germination of eelgrass seeds usually peaks in late autumn and early spring (Orth \& Moore 1983b, Robertson \& Mann 1984) and, therefore, the number of seedlings registered in May represents minimum estimates due to seedling formation and mortality during winter. The number of patches formed from seedlings declined quickly following colonization as only $47 \%$ (range 37 to $55 \%$ ) remained as individual patches until late summer. This decline was due to mortality (24 to $32 \%$ ) and coalescence with adjacent vegetation ( 13 to $37 \%$ ). The fate of seedlings that coalesced with other patches is unknown.

Branching of surviving seedlings increased mean shoot number from 1.1 (range 1 to 3 ) shoots per genet in May to 3.7 (range 1 to 8 ) shoots per genet in August. This 4 -fold increase is similar to the branching frequency observed in other perennial eelgrass populations following 5 to 6 mo of seedling growth (Orth \& Moore 1983b, Robertson \& Mann 1984). After 1 yr of growth $11 \%$ of the 1990 seedling cohort had survived as individual patches and none persisted until September 1992. In contrast, 19 to $24 \%$ of the larger seedling cohort of 1991 remained as individual patches in September 1992. These surviving seedlings had increased to an average of 6 (range 1 to 15) shoots per genet. 


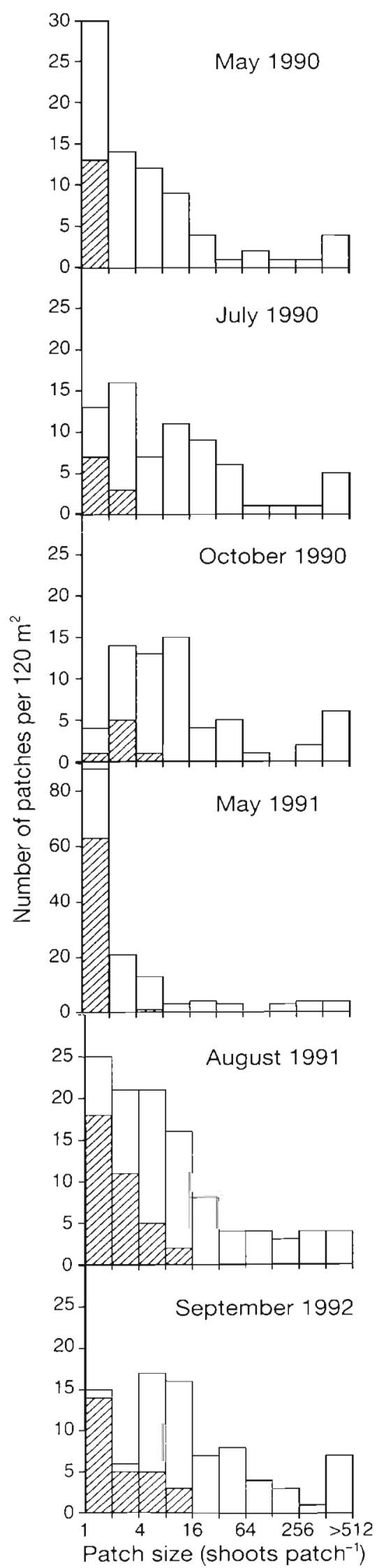

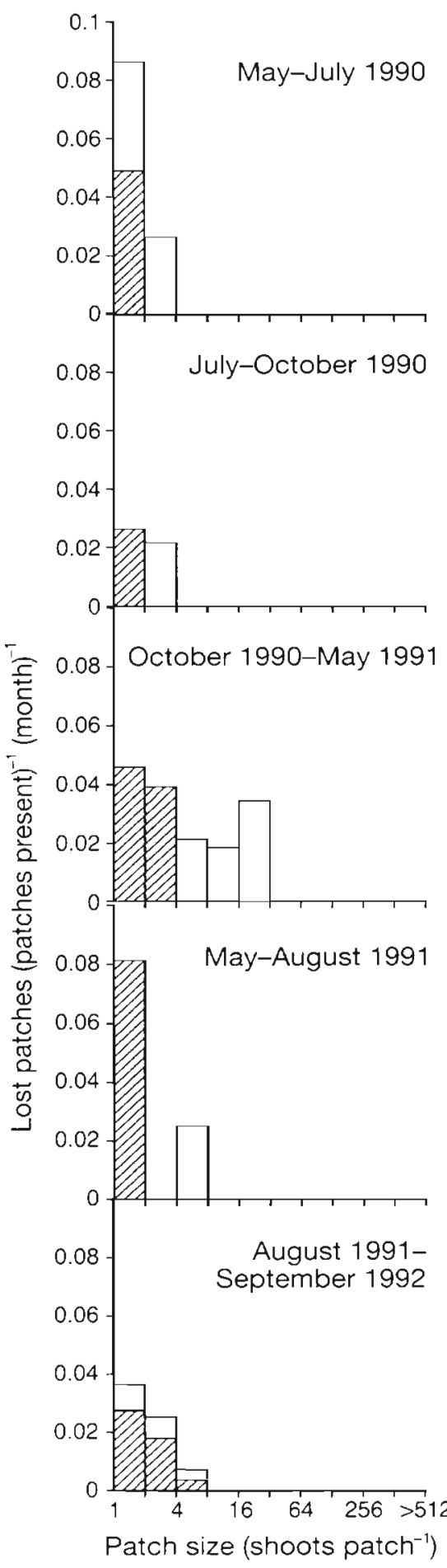

Fig. 2. Zostera marina. Seasonal changes of logarithmic size distribution of eelgrass patches in a permanent plot (Plot I, $120 \mathrm{~m}^{2}$ ) and the relative mortality of patches within each size class. Hatched areas show patches established from seedlings during the study period (May 1990 to September 1992)

\section{Patch growth}

Lateral patch growth was independent of the orientation of growth relative to the direction of the prevailing wind or wave action (ANOVA, p = $0.75)$, consistent with the approximate circular form of most studied patches. The patch growth rate was also independent of patch size (Fig. 5) within the studied range (diameter 0.2 to $10 \mathrm{~m}$ ). Mean patch growth rate was highest during summer of both years [1.30 \pm 0.09 (SE) and $\left.1.42 \pm 0.18 \mathrm{~mm} \mathrm{~d}^{-1}\right]$, coinciding with high irradiance and high shoot growth rates, and declined to a minimum $\left(-0.04 \pm 0.05 \mathrm{~mm} \mathrm{~d}^{-1}\right)$ during winter (Fig. 6). The mean net lateral growth measured from April 1990 to May 1991 was $16 \mathrm{~cm} \mathrm{yr}^{-1}$ (range -26 to $45 \mathrm{~cm} \mathrm{yr}^{-1}$ ) and the median growth rate was $19.0 \mathrm{~cm} \mathrm{yr}^{-1}$ (0 to $31 \mathrm{~cm} \mathrm{yr}^{-1}$, 10 to $90 \%$ fractiles) (Fig. 6).

\section{Shoot growth}

Relative leaf elongation rates measured in August on eelgrass shoots growing at the centre of patches of different dimensions were independent of patch size $(r=0.03$, $p=0.92, n=15$ ). The relative leaf elongation rate showed little variability [14.6 to $15.8 \mathrm{~mm}$ leaf (m leaf) ${ }^{-1} \mathrm{~d}^{-1}$ ] among patches (Fig. 7). Likewise, the relative shoot elongation rate did not change systematically with the distance to patch edge $(r=0.12, p=0.45$, $n=42$ ) as elongation was 13.5 to $15.8 \mathrm{~mm} \mathrm{~m}^{-1} \mathrm{~d}^{-1}$ at the edge and 13.0 to $15.8 \mathrm{~mm} \mathrm{~m}^{-1} \mathrm{~d}^{-1}$ within the vegetation (Fig. 7). Shoot size did not change with distance to patch edge either and absolute leaf elongation rates were therefore also independent of location.

\section{DISCUSSION}

\section{Patch formation and mortality}

The studied area was relatively protected and supported a large eelgrass population. These conditions 


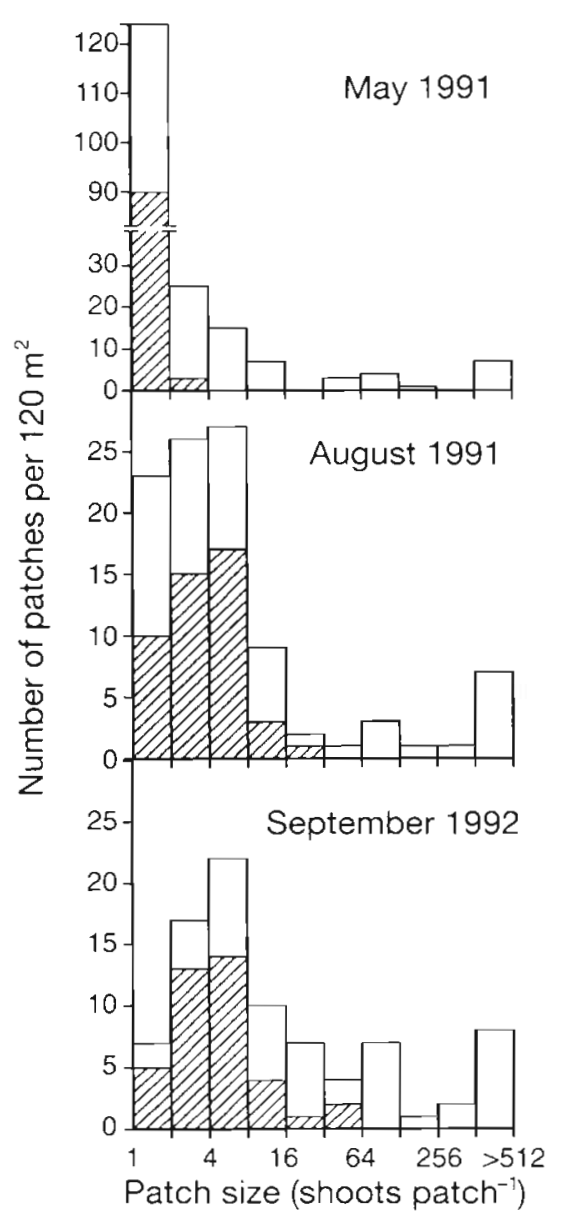

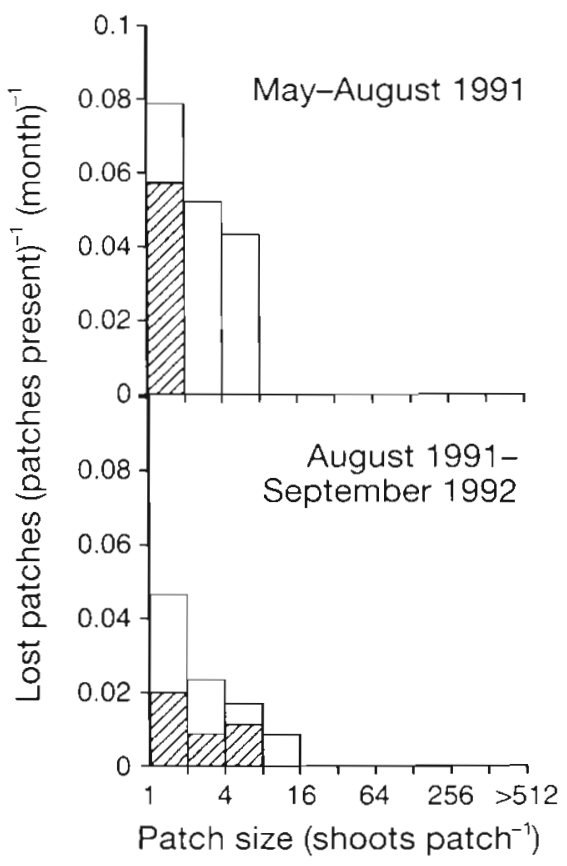

Fig. 3. Zostera marina. Seasonal changes of logarithmic size distribution of eelgrass patches in a permanent plot (Plot $11,120 \mathrm{~m}^{2}$ ) and the relative mortality of patches within each size class. Hatched areas show patches established from seedlings during the study period (May 1991 to September 1992)
26 seeds $\mathrm{m}^{-2}$ in bare areas (Olesen 1993). Thus, the possible formation of new patches through seedling establishment was high. Winters were mild and without ice formation during our study period, which may have enhanced patch survival and lateral spread of established meadows. The study period did not deviate from the average in terms of strength and frequency of storms, but particularly strong storms that are able to eradicate very large patches (Wyer et al. 1977, Orth \& Moore 1983a) did not occur. Accordingly, the patch dynamics observed here are likely to reflect patterns without major storm or ice disturbances, but rates of patch formation and mortality and threshold sizes for high rates of survival should be site and time specific.

The skewed patch size distribution (Figs. $2 \& 3$ ) is indicative of the fast patch formation and mortality observed here. Hence, the description of the rapid turnover of small patches requires high sampling frequency because new shoots may form and vanish unnoticed during longer time intervals. Formation of small patches was certainly influenced patch dynamics because the surrounding populations should have provided many seeds for patch recruitment while the protected location should have enhanced survival of patches down to small sizes. In early spring, prior to the main pulse of seedling appearance, the seed bank consisted of 1048 seeds $\mathrm{m}^{-2}$ inside dense eelgrass stands and fastest during winter and spring, whereas patch mortality occurred throughout the year in the 2 experimental areas. Mortality declined sharply with patch size and was restricted to patches with less than 32 shoots during this investigation. Hence, rigid branching and patch expansion should increase the likelihood of survival.

Table 1. Zostera marina. Number of patches established through seedlings in $120 \mathrm{~m}^{2}$ plots (Plots I \& II) during spring 1990 and 1991 and cumulative survival and losses due to fusion with adjacent patches and mortality until autumn 1992. Number of patches relative to the initial seedling density is shown in parentheses

\begin{tabular}{|c|c|c|c|c|c|c|}
\hline & \multicolumn{2}{|c|}{ Number of seedlings } & \multicolumn{2}{|c|}{ Fusion } & \multicolumn{2}{|c|}{ Mortality } \\
\hline & 1 & II & I & II & I & II \\
\hline 1990 cohort & 19 & & & & & \\
\hline Oct 1990 & $7(0.37)$ & & $7(0.37)$ & & $5(0.26)$ & \\
\hline May 1991 & $2(0.11)$ & & $7(0.37)$ & & $10(0.53)$ & \\
\hline Aug 1991 & $1(0.05)$ & & $8(0.42)$ & & $10(0.53)$ & \\
\hline Sep 1992 & $0(0)$ & & $9(0.47)$ & & $10(0.53)$ & \\
\hline 1991 cohort & 62 & 93 & & & & \\
\hline Aug 1991 & $34(0.55)$ & $46(0.49)$ & $8(0.13)$ & $25(0.27)$ & $20(0.32)$ & $22(0.24)$ \\
\hline Sep 1992 & $15(0.24)$ & $18(0.19)$ & $11(0.18)$ & $40(0.43)$ & $36(0.58)$ & $35(0.38)$ \\
\hline
\end{tabular}



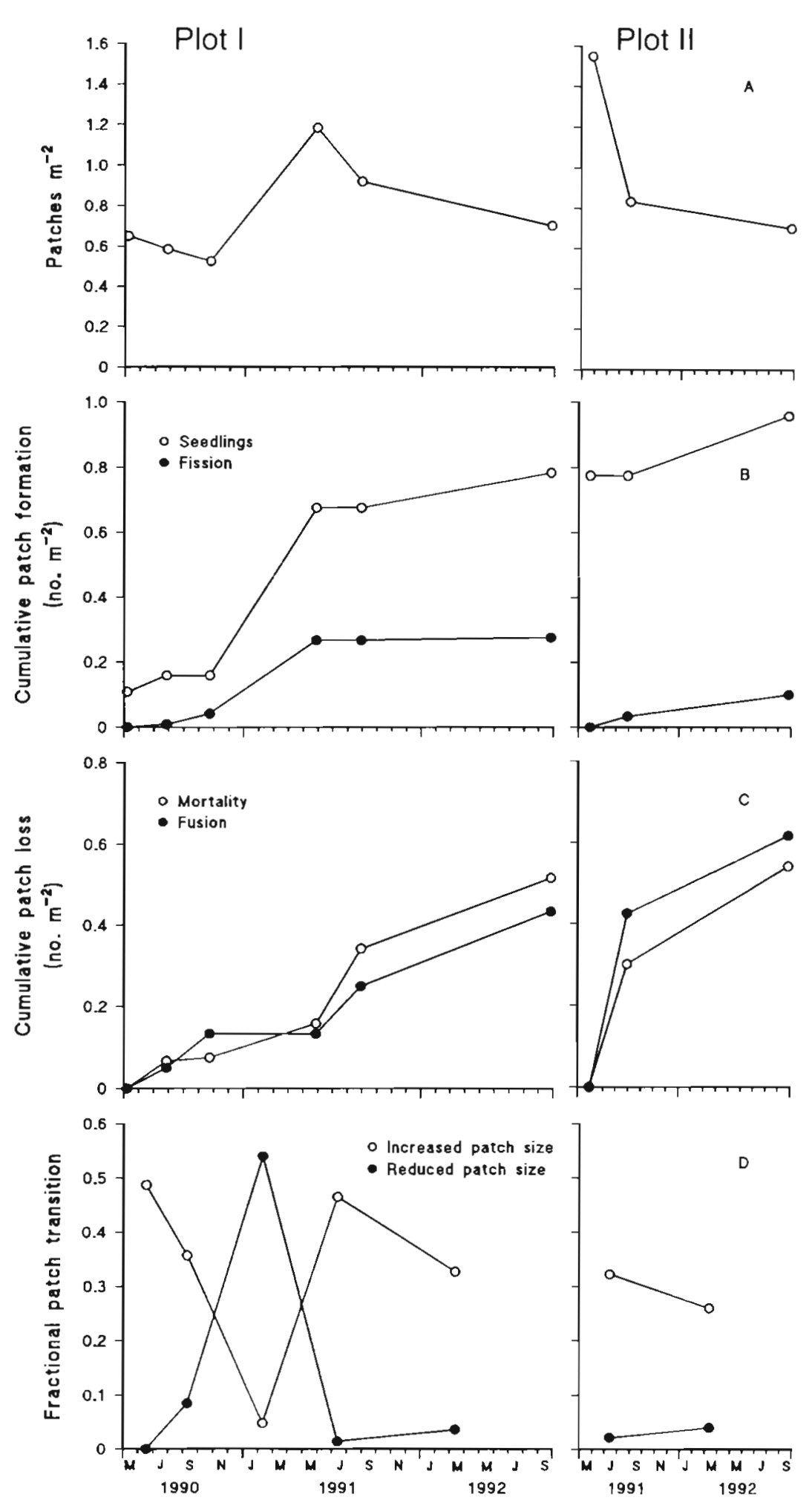

Fig. 4. Zostera marina. Seasonal changes in (A) total number of eelgrass patches in permanent plots $\left(120 \mathrm{~m}^{2}\right)_{i}(B)$ cumulative number of new patches appearing between sampling dates through seedling establishment and fragmentation of larger patches; (C) cumulative losses of patches through mortality and fusion; (D) proportion of total number of patches moving to a larger $(0)$ or smaller $(\bullet)$ size-class between sampling dates
The average number of shoots produced per genet was 6 (range 1 to 15 shoots genet ${ }^{-1}$ ) by the end of the second growth season. Assuming a mean annual production of 1 sidebranch shoot ${ }^{-1}$, as observed for established eelgrass populations at the same location (Olesen \& SandJensen 1994), the new patches will not reach the critical minimum size before 5 yr of growth or, at best, after 3 yr. The mortality risk is expected to be minimal thereafter, provided physical forces are not extreme.

The observed decline of patch mortality with increasing patch size strongly supports the existence of a minimum patch size needed to ensure high survival, presumably because the shoots provide mutual protection and need a long time for rhizome and roots to develop and become firmly anchored. Physiological integration and support within the genet may enhance survival as the time elapsed since establishment increases. Likewise, high mortality was restricted to small patches of the Mediterranean seagrass Cymodocea nodosa (Duarte \& Sand-Jensen 1990a) and the stream macrophyte Callitriche cophocarpa (Sand-Jensen \& Madsen 1992). The threshold size necessary to reduce mortality due to physical forces should, however, depend on the strength of wave and storm events because shelter within the vegetation decreases with current velocity (Fonseca et al. 1982). Established eelgrass stands should be able to withstand high currents due to the mutually protecting structure of patches and a high capacity for patch maintenance achieved by continuous shoot recruitment through rhizome branching (Olesen \& Sand-Jensen 1994).

The growth rate of eelgrass shoots during summer was independent of patch size and distance to the patch margin (Fig. 7). Thus, the supposedly more protected conditions away from the patch margin did not influence the relative leaf elongation rate. Possible explanations of this result could be that disturbance does not influence 
eelgrass leaf elongation, that disturbance was too small to have an effect during the experimental period, or that increased disturbance was exactly offset by greater light availability at the patch margin. It is also possible that protection among shoots is established close to the patch edge, because the slow horizontal growth and intensive

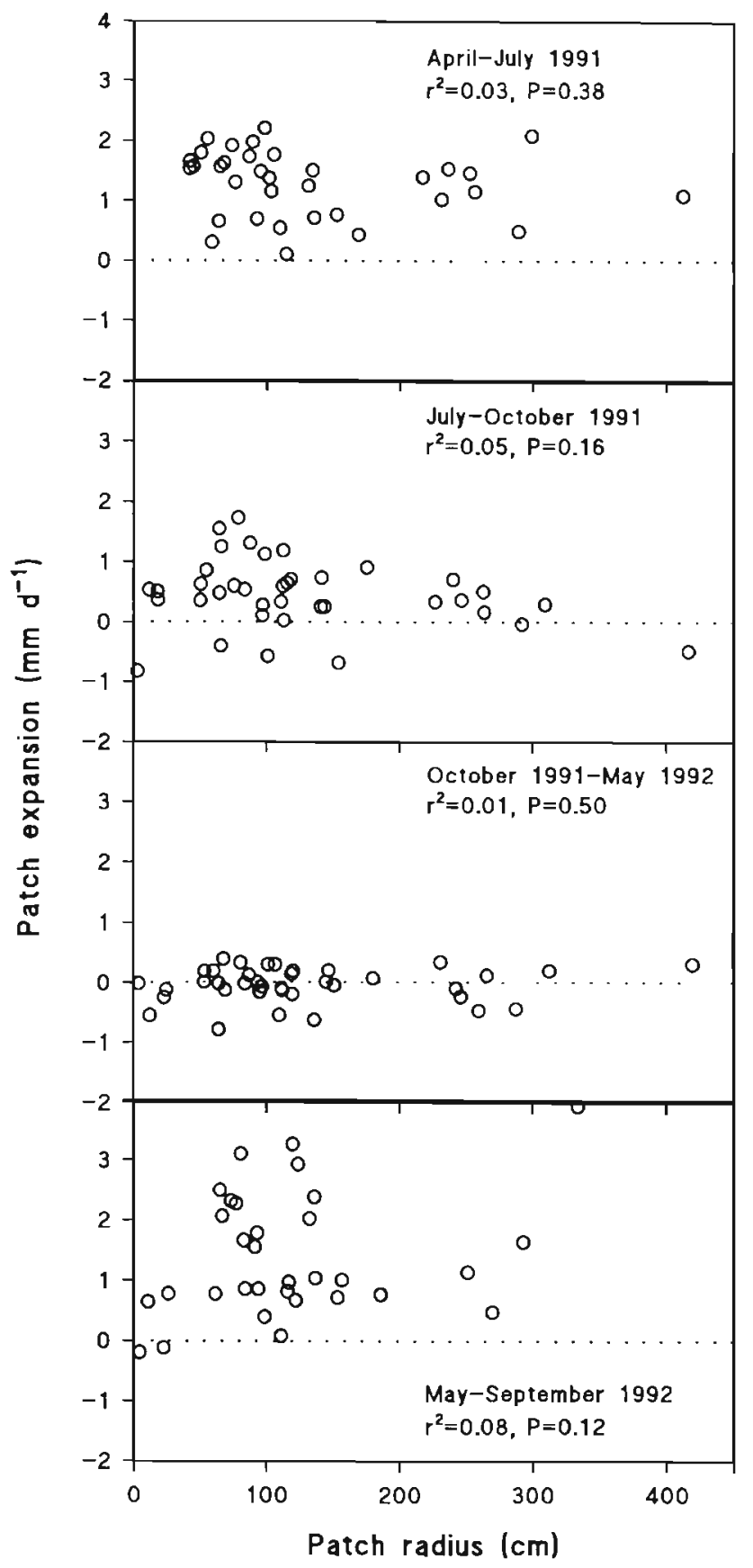

Fig. 5. Zostera marina. Relationship between eelgrass patch elongation rate and patch radius measured from April 1990 to September 1991 Symbols are average values of elongation rates in 4 directions of each patch. $\mathrm{r}^{2}$ : coefficient of determination; P: significance level branching of the rhizome generate dense plant cover and thereby strong attenuation of flow velocity within less than $25 \mathrm{~cm}$ from the patch edge (Gambi et al. 1990).

Areal seed production of perennial eelgrass populations is high (3400 to 17600 seeds $\mathrm{m}^{-2}$ in this area; Olesen 1993) compared to other perennial aquatic plants (Madsen 1991). The negatively buoyant seeds of eelgrass may have limited spread, but dispersal can be enhanced by the spread of floating inflorescences. A small dispersal range of eelgrass seeds may contribute to the maintenance of existing populations following small-scale disturbances by filling out open gaps within the vegetation as observed here. Colonization from seedlings after large-scale declines should, however, depend on the distance to seed-producing populations outside the perturbed area. Moreover, seed dis-
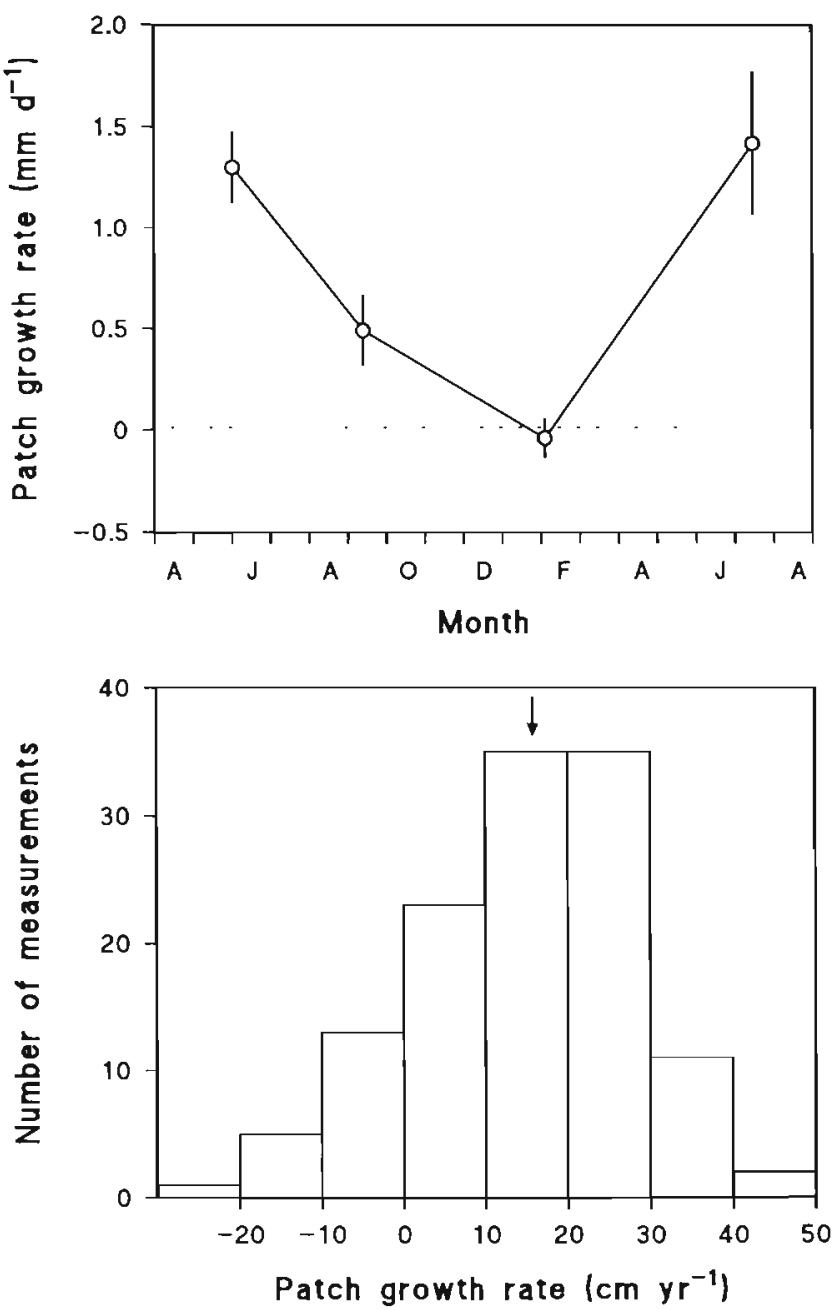

Fig. 6. Zostera marina. Seasonal changes in eelgrass patch elongation rate (mean $\pm 95 \% \mathrm{CL}$ ) and the frequency distribution of net lateral growth of eelgrass patches from April 1990 to May 1991 measured in 4 positions of each patch $(\mathrm{n}=124)$. Arrow: mean growth rate 

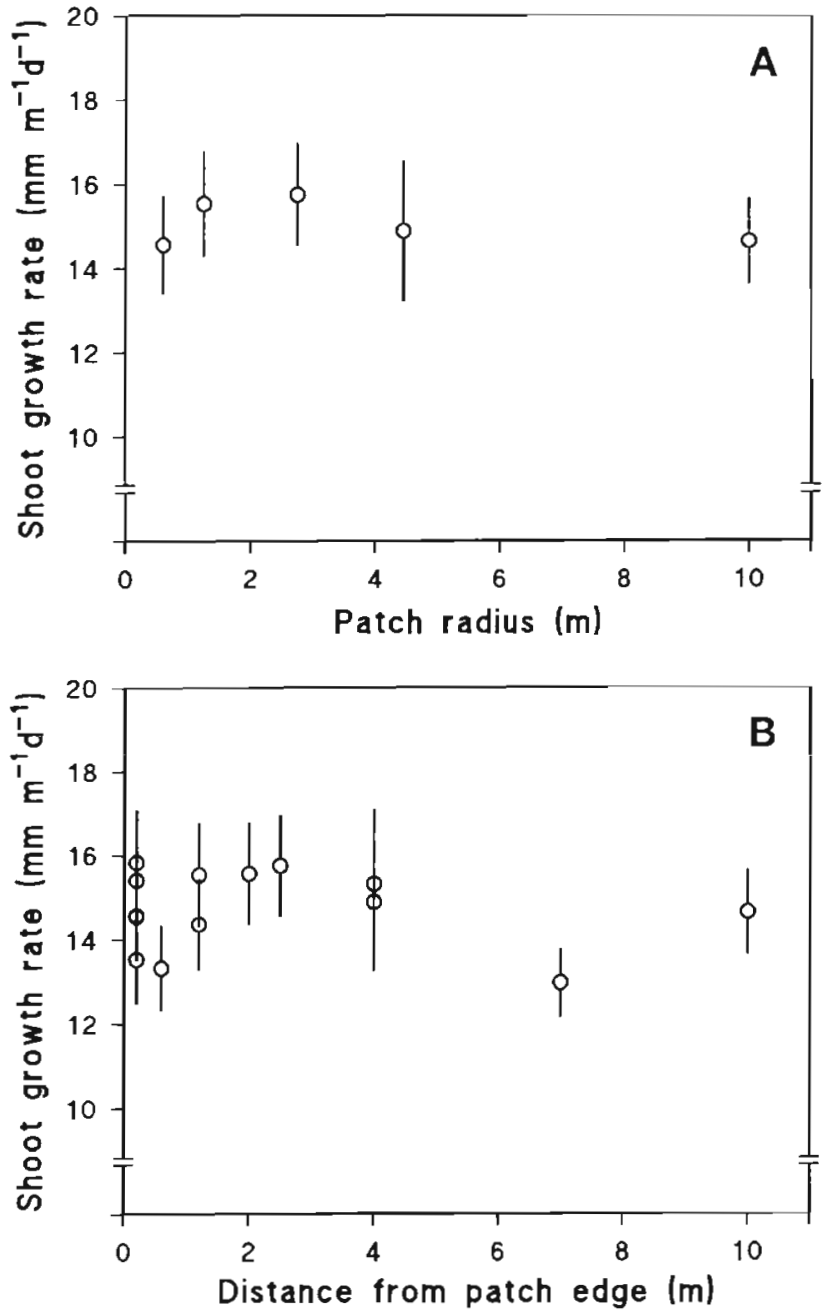

Fig. 7. Zostera marina. Relationship between (A) eelgrass shoot growth rate measured at the centre of each patch and patch size and $(B)$ eelgrass shoot growth rate measured at the patch edge and at increasing distance from the patch edge (mean $\pm 95 \% \mathrm{CL}$ )

persal to open areas may be infrequent, as observed for Posidonia australis, which only displayed successful seedling colonization in a protected barrier estuary, acting as a trap for floating $P$. australis fruits (West et al. 1989j. Thus, considering the high germination success reported for eelgrass seeds (Churchill 1983, Moore et al. 1993), colonization of new areas is probably restricted by a limited dispersibility and the subsequent successful development of seedlings into patches.

\section{Expansion of patches}

Eelgrass patches expanded between April and September (Fig. 6), when leaf growth was maximal, but variability among patches remained high and some patches did not grow at all. During winter most patch margins withdrew, probably because their lateral growth was arrested by low irradiance and physical exposure damaged and removed shoots at the edges. The patches were of greatly variable size but patch radius and radial growth were independent of compass direction, suggesting that physical exposure was not sufficiently oriented from a particular direction to influence patch form and lateral growth. In unidirectional flows in streams patches are often elongated and streamlined in the flow direction to minimize physical exposure and drag (Sand-Jensen \& Madsen 1992) and in tidal waters eelgrass patches may develop perpendicular to the flow direction (Fonseca et al. 1983). Similar deviation from a circular form should be anticipated here if wind and wave exposure had been from a prevailing direction, but we found no such trends.

The eelgrass patches expanded, on average, by $16 \mathrm{~cm} \mathrm{yr^{-1 }}$ with ranges from -26 to $45 \mathrm{~cm} \mathrm{yr}^{-1}$ (Fig. 6). There are no constraints on patch recession because even large patches can disappear during strong storms (Orth \& Moore 1983a, den Hartog 1987), whereas the maximum expansion is limited by the possible horizontal growth of eelgrass rhizomes. The slow lateral growth of eelgrass is similar to that of large seagrass species of Posidonia 10 to $30 \mathrm{~cm} \mathrm{yr}^{-1}$; Clarke \& Kirkman 1989), which display very slow recolonization rates (60 to 100 yr; Kirkman \& Kuo 1990) following largescale disturbance. In contrast, seagrass species with opportunistic growth patterns expand more rapidly by horizontal runners (e.g. Duarte \& Sand-Jensen 1990a: $1.6 \mathrm{~m} \mathrm{yr}^{-1}$ for Cymodocea nodosa; Brouns 1987: ca $8 \mathrm{~m}$ $\mathrm{yr}^{-1}$ for Syringodium isoetifolium) and can more effectively reach suitable more remote open space and accommodate to physical disturbances such as subaqueous dunes moving several metres $\mathrm{yr}^{-1}$ (Marbá et al. 1994). However, annual eelgrass populations, which develop each year from seeds, can also display rapid expansion rates $\left(30 \mathrm{~m} \mathrm{yr}^{-1}\right)$, following major improvements of growth conditions (Harrison 1987). These populations occur in the intertidal zone under highly fluctuating temperature, salinity and occasional emersion (Keddy \& Patriquin 1978, Robertson \& Mann 1984 ) and abundance is presumably influenced by the seed set of the preceding year, as most eelgrass seeds remain dormant for less than 1 yr (Harrison 1991, Moore et al. 1993).

The annual change in areal cover of the eelgrass populations studied here should depend greatly on the size distribution of patches, their formation and mortality rates in addition to the lateral spread. During the study period, no patches with more than 32 shoots died, and mean lateral growth $\left(16 \mathrm{~cm} \mathrm{yr}^{-1}\right)$ was independent of patch size. Annual areal expansion will, therefore, be much faster in situations with many small 
patches (260\% in $0.1 \mathrm{~m}^{2}$ patches, $65 \%$ in $1 \mathrm{~m}^{2}$ patches) rather than in situations with few large patches $(19 \%$ in $10 \mathrm{~m}^{2}$ patches). Accordingly, extensive recruitment of new patches via seedlings should greatly increase the rate of eelgrass colonization. Based on the seedling establishment and subsequent survival and growth observed in this study, a $100 \mathrm{~m}^{2}$ area will require $9 \mathrm{yr}$ to reach complete cover. This estimate provides an optimistic potential for the spread of the present meadows, neglecting the influence of fusion of patches and of extensive mortality which may occur under particularly unsuitable periods. However, coverage of a similar $100 \mathrm{~m}^{2}$ area by rhizome intrusion $\left(16 \mathrm{~cm} \mathrm{yr}^{-1}\right)$ from surrounding populations at the edge would require 35 yr. Thus, provided the annual growth from seeds is high, eelgrass colonization may be relatively fast as observed in The Netherlands, where the closure of Lake Grevelingen resulted in an increase in eelgrass areal cover from 1200 to 4400 ha during a 10 yr period (Verhagen \& Nienhuis 1983).

In conclusion, eelgrass colonization proceeded by a combination of seedling recruitment, patch establishment and subsequent horizontal growth. The lateral growth rate of established patches was slow and, therefore, seed production, seedling establishment and subsequent patch development appear to be crucial to large-scale eelgrass recovery. However, because the surviving seed-producing populations are much reduced and physical disturbance is enhanced by loss of the former widespread protective eelgrass cover in Denmark and many other regions, we predict that eelgrass recovery, if indeed it occurs, will take several decades after nutrient loading has been reduced and water transparency improved.

Acknowledgements. This work was supported by grants from Limfjords Kommiteen to B.O. and The Danish Natural Science Research Council (grant no. 11-7795) to K.S.J. We thank D. Søndergård for assistance during field work and J. Borum C. M. Duarte and M. F. Pedersen for valuable discussions and comments on the manuscript.

\section{LITERATURE CITED}

Birch, W. R., Birch, M. (1984). Succession and pattern of tropical intertidal seagrasses in Cockle Bay, Queensland, Australia: a decade of observations. Aquat. Bot. 19 $343-367$

Brouns, J. J. W. M. (1987). Growth patterns in some Indo-West Pacific seagrasses. Aquat. Bot. 28: 39-61

Cambridge, M. L., McComb, A. J. (1984). The loss of seagrasses in Cockburn Sound, Western Australia. I. The time course and magnitude of seagrass decline in relation to industrial development. Aquat. Bot. 20: 229-243

Churchill, A. C. (1983). Field studies on seed germination and seedling development in Zostera marina L. Aquat. Bot. 16: $21-29$
Clarke, S. M., Kirkman, H. (1989). Seagrass dynamics. In: Larkum, A. W. D., McComb, A. J., Shepherd, S. A. (eds.) Biology of seagrasses. A treatise on the biology of seagrasses with special reference to the Australian region. Elsevier, Amsterdam, p. 304-334

den Hartog, C. (1987). 'Wasting disease' and other dynamic phenomena in Zostera beds. Aquat. Bot. 27: 3-14

den Hartog, C., Polderman, P. J. G. (1975). Changes in the seagrass populations of the Dutch Waddenzee. Aquat. Bot. $1141-147$

Duarte, C. M., Sand-Jensen, K. (1990a). Seagrass colonization: patch formation and patch growth in Cymodocea nodosa. Mar. Ecol. Prog. Ser. 65: 193-200

Duarte, C. M., Sand-Jensen, K. (1990b). Seagrass colonization: biomass and shoot demography in Cymodocea nodosa patches. Mar. Ecol. Prog. Ser. 67: 97-103

Fonseca, M. S., Fisher, J. J., Zieman, J. C., Thayer, G. W. (1982). Influence of the seagrass, Zostera marina L., on current flow. Estuar. coast. Shelf Sci. 15: 351-364

Fonseca, M. S., Zieman, J C., Thayer, G. W., Fisher, J. S. (1983). The role of current velocity in structuring eelgrass (Zostera marina L.) meadows. Estuar. coast. Shelf Sci. 17: $367-380$

Gambi, C. G., Nowell, A. R. M., Jumars, P. A. (1990). Flume observations on flow dynamics in Zostera marina (eelgrass) beds. Mar. Ecol. Prog. Ser. 61: 159-169

Giesen, W. B. J. I., van Katwijk, M. M., den Hartog, C. (1990). Eelgrass conditions and turbidity in the Dutch Wadden Sea. Aquat. Bot. 37: 71-85

Harrison, P. G. (1987). Natural expansion and experimental manipulation of seagrass (Zostera spp.) abundance and the response of infaunal invertebrates. Estuar. coast. Shelf Sci. 24: 799-812

Harrison, P. G. (1991). Mechanisms of seed dormancy in an annual population of Zostera manina (eelgrass) from The Netherlands. Can. J. Bot. 69: 1972-1976

Keddy, C. J., Patriquin, D. G. (1978). An annual form of eelgrass in Nova Scotia. Aquat. Bot. 5: 163-170

Kemp, W. M., Twilley, R. R., Stevenson, J. C., Boynton, W. R., Means, J. C. (1983). The decline of submerged vascular plants in upper Chesapeake Bay: summary of results concerning possible causes. J. mar. technol. Soc. 17 $78-89$

Kirkman, H., Kuo, J. (1990). Pattern and process in southern Western Australian seagrasses. Aquat. Bot. 37: 367-382

Kirkman, H., Reid, D. D. (1979). A study of the role of the seagrass Posidonia australis in the carbon budget of an estuary. Aquat. Bot. 7: 173-183

Larkum, A. W. D., den Hartog, C. (1989). Evolution and biogeography of seagrass. In: Larkum, A. W. D., McComb, A. J., Shepherd, S. A. (eds.) Biology of seagrasses. A treatise on the biology of seagrasses with special reference to the Australian region. Elsevier, Amsterdam, p. $112-156$

Larkum, A. W. D., West, R. J. (1990). Long-term changes of seagrass meadows in Botany Bay, Australia. Aquat. Bot. 37: $55-70$

Madsen, J. K. (1991). Resource allocation at the individual plant level. Aquat. Bot. 41. 67-86

Marbá, N., Cebrian, J., Enriquez, S., Duarte, C. M. (1994). Migration of large scale subaqueous bedforms measured using seagrasses (Cymodocea nodosa) as tracers. Limnol. Oceanogr. (in press)

Moore, K. A., Orth, R. J., Nowak, J. F. (1993). Environmental regulation of seed germination in Zostera marina $L$. (eelgrass) in Chesapeake Bay: effects of light, oxygen and sediment burial. Aquat. Bot. 45: 79-91 
Olesen, B. (1993). Population dynamics of eelgrass. Ph.D thesis, University of Aarhus

Olesen, B., Sand-Jensen, K. (1994). Demography of shallow eelgrass (Zostera marina) populations: shoot dynamics and biomass development. J. Ecol. (in press)

Orth, R. J., Moore, K. A. (1983a). Chesapeake Bay: an unprecedented decline in submerged aquatic vegetation. Science 222: 51-52

Orth, R. J., Moore, K. A. (1983b). Seed germination and seedling growth of Zostera marina L. (eelgrass) in the Chesapeake Bay. Aquat. Bot. 15: 117-131

Petersen, C. G. J. (1914). Om Bændeltangens (Zostera marina) aars-produktion i de danske farvande. Jungersen, H. F. E., Warming, E. (eds.) Mindesknift for Japetus Steenstrups Fødsel, Vol. 9. Bianco Lunos Bogtrykkeri, Copenhagen, p. 1-20 (in Danish)

Phillips, R. C. (1984). The ecology of eelgrass meadows in the Pacific northwest: a community profile. U.S. Fish. Wildl. FWS/Serv. OBS 84/24: 1-85

Rasmussen, E. (1977). The wasting disease of eelgrass (Zostera marina) and its effect on environmental factors and fauna. In: McRoy, C. P., Helfferich, C. (eds.) Seagrass ecosystems, a scientific perspective. Marcel Dekker, New York, p. $1-51$

Robertson, A. I., Mann, K. H. (1984). Disturbance by ice and life-history adaptations of the seagrass Zostera marina. Mar. Biol. 80: 131-141

This article was presented by G. W. Thayer, Beaufort, North Carolina, USA
Sand-Jensen, K. (1975). Biomass, net production and growth dynamics in an eelgrass (Zostera marina L.) population in Vellerup Vig, Denmark. Ophelia 14: 185-201

Sand-Jensen, K., Madsen, T. V. (1992). Patch dynamics of the stream macrophyte, Callitriche cophocarpa. Freshwat. Biol. 27: 277-282

Setchel, W. A. (1929). Morphological and phenological notes on Zostera marina L. Univ. Calif. Publs Bot. 14: 389-452

Smith, I. R. (1979). Hydraulic conditions in isothermal lakes. Freshwat. Biol. 9: 119-145

Verhagen, J. H. G., Nienhuis, P. H. (1983). A simulation model of production, seasonal changes in biomass and distribution of eelgrass (Zostera marina) in Lake Grevelingen. Mar. Ecol. Prog. Ser. 10: 187-195

West, R. J., Larkum, A. W. D., King, R. J. (1989). Regional studies - seagrasses of south Eastern Australia. In: Larkum, A. W. D., McComb, A. J., Shepherd, S. A. (eds.) Biology of seagrasses. A treatise on the biology of seagrasses with special reference to the Australian region. Elsevier, Amsterdam, p. 230-255

Williams, S. L. (1988). Disturbance and recovery of a deep-water Caribbean seagrass bed. Mar. Ecol. Prog. Ser. 42: 63-71

Williams, S. L. (1990). Experimental studies of Caribbean seagrass bed development. Ecol. Monogr. 60: 449-469

Wyer, D. W., Boorman, L. A., Waters, R. (1977). Studies on the distribution of Zostera in the outer Thames Estuary. Aquaculture 12: $215-227$

Manuscript first received: September 1, 1993

Revised version accepted: December 17, 1993 